\title{
THE IMPACT OF NON-FINANCIAL FACTORS ON THE ORGANIZATION OF ENVIRONMENTAL ACCOUNTING IN TEXTILE ENTERPRISES IN HO CHI MINH CITY
}

\author{
NGUYEN THANH TAI, LANG THI MINH THAO \\ Ministry Of Industry \& Trade Industrial University Of Ho Chi Minh City; \\ nguyenthanhtaiacc@gmail.com,ltmthao72@gmail.com
}

\begin{abstract}
.
In this article, the authors study non-financial factors affecting the organization of environmental accounting in textile enterprises in HCMC. The author uses multivariate regression model after the Cronbach Alpha scales have been verified and the exploratory factors have been analyzed. The research results show that there are 4 factors that are stakeholders, staff qualifications, regulations, perceptions of leaders about environment and environmental accounting that have a positive relationship to the organization of environmental accounting in textile enterprises in Ho Chi Minh City.
\end{abstract}

Keywords. Environmental accounting, influencing factors, non-financial factors.

\section{INTRODUCTION}

The first environmental accounting introduced in Vietnam is the project "Environmental management Accounting for small and medium enterprises in Southeast Asia" (EMA-SEA), this project is implemented in 4 countries: Thai Lan, Philippines, Indonesia, Vietnam. This project is funded by the German Ministry of Economic Cooperation and Development, managed and ran by the International Capacity Building Organization (InWent), from 11/2003 to 08/2007, the purpose of this project is to help businesses and organizations promote business activities in a sustainable manner, better trade integration through transfer knowledge and skills in environmental accounting (Nguyen Thanh Tai, 2012).

Through the collection, review and general evaluation of domestic and foreign studies related to the topic, the research author has shown that environmental accounting has been concerned not only in foreign countries but also In Vietnam, environmental accounting has become a tool to help manage and control production and business activities better, creating a huge competitive advantage for businesses in the trend of globalization. Although environmental accounting is important, through observation and understanding, the application of environmental accounting to enterprises in Vietnam is still little (Environmental accounting is often hidden in accounting and management accounting, information is very little, there is no clear classification, separation, and clarity), especially for enterprises in the textile and garment industry - which brings a great source of income for Vietnam and also has an strong impact to the surrounding environment.

Based on the review study, the author uses qualitative research method which is based on in-depth interviews with 9 experts who have a lot of experience in teaching accounting, as auditors, who hold the high position in textile enterprises in HCMC. Interviews to find out which non-financial factors affect the organization of environmental accounting in textile enterprises in Ho Chi Minh City? Next, the author designed the research model, built and tested the scales of the factors affecting the organization of environmental accounting in textile enterprises in Ho Chi Minh City, from which given recommendations for promoting the application of environmental accounting in Ho Chi Minh City in particular and Vietnam in general. 
THE IMPACT OF NON-FINANCIAL FACTORS ON THE ORGANIZATION OF ENVIRONMENTAL 31 ACCOUNTING IN TEXTILE ENTERPRISES IN HO CHI MINH CITY

\section{THEORETICAL FRAMEWORK AND RESEARCH HYPOTHESIS}

\subsection{Theoretical framework \\ Contingency theory of Organizations}

The 1960s the concept of contingency theory of Organizations was developed from organizational theory. In 1960, organizational theory developed a comprehensive Contingency theory after undergoing a major upheaval (Otley, 1980). Burns and Stalker (1961) examined the defense electronics industry in Scotland and examined the impact of environmental uncertainty on an organization's structure. In an unstable environment, the instability of the environment means that planning ahead is almost impossible. Woodward (1965) argues that for companies in a relatively stable environment, mass production technologies will be most effective. Thompson (1967) identifies three types of interdependence among affiliated units that are widely available in modern organizations (synthesized, sequential, and reciprocal) and consider interrelationships between levels. Interaction between affiliated units. Perrow (1967) emphasizes issues related to the habit or nature of technology. Lawrence and Lorsch (1967) argue that each organization has a unique environment and responds to this environment by developing unique attributes. An organization needs to arrange tasks appropriately, and propose the establishment of different departments for different tasks.

Many studies in the field of KT use random theory as a basis to explain the impact of factors such as firm size, administrator's support, staff's level, ... on the effectiveness of public Technical cooperation in enterprises (Philippe Chapellier \& ctg, 2010; Ahmad \& Mohamed Zabri, 2015). According to Chapman, (1997), Chenhall, (2003), Gerdin and Greve, (2004) studies of management accounting based on random theory have also been around for a long time. The random approach to management accounting is based on the assumption that no suitable accounting system applies to all organizations in all cases, the specific characteristics of a system Appropriate accounting systems will depend on the specific circumstances found by the organization (Otley, 1980). According to Mintzberg (1979), the groups of factors that determine the number of years of establishment and the size of the enterprise, the technical system that the enterprise uses, the surrounding environment and the strength of the contacts have an impact on the structure of Business According to Chenhall et al. (1981), the factors of environment, technology, scale, and structure have a significant impact on business processes and decision making. According to Otley (1980), the uncertainty factors affect the design of enterprises and international economic technical tools. Waterhouse and Tiessen (1983) have shown that the structure of enterprises depends on the technology and operating environment of enterprises and the efficiency of the international economic system depends on the structure of enterprises. Halma and Laats (2002) see random variables as external factors (environmental features) and internal (technology, organizational, and strategic aspects).

Contingency Theory helps the author visualize the impact of factors from inside and outside to the organization of environmental accounting in enterprises. The factors of organizational structure, enterprise size, staff level, technology, ... are uncertain, so that the environmental accounting organization to achieve efficiency requires conformity with the characteristics of the organization.

\section{Institutional theory}

According to DiMaggio and Powell, (1983), the theory of institutional theory is based mainly on social and economic theory. This theory suggests that the establishment of the company's organizational and operational structure is influenced by three factors: regulation (coercive pressure), diffusion (pressure of imitation), norm (pressure diagnostic force). First, the current regulations will put pressure on organizations to comply with the issued regulations. Governments and regulators can use their powers to intervene and influence businesses that force businesses to comply with current regulations. Second, diffusion creates a pressure to imitate that is in a situation when the company faces ambiguous situations and is not sure to apply proven or practical techniques to the public. Other competitive companies. Finally, the Code is a pressure to emphasize the importance of voluntary implementation, the application of standards (given by professional organizations) to reduce pressure on coercion. 
This theory explains that environmental accounting organizations need regulation (mandatory), standards of implementation guidelines as well as a pressure to imitate. The combination of these three factors will be the motivation for enterprises to implement environmental accounting in enterprises, because when the benefits from the organization of environmental accounting are not really clear for enterprises, teamwork Environmental accounting functions will be difficult to become a reality if there is no pressure on businesses.

\subsection{Research hypothesis}

Based on studies by Bartolomeo, et al, (2000), Faizah Mohd Khalid, Beverley Rae Lord and Keith Dixon (2012), Altohami Otman Alkisher (2013), Che Zuriana Muhammad Jamila, Rapiah Mohamedb, Faidzulaini Muhammadc, Amin Alid (2014), Chang (2007), at the same time combining the results of indepth interviews with experts, the author generalized the non-financial factors affecting the organization of environmental accounting in textile enterprises in Ho Chi Minh city as follows:

Stakeholders: Similar to the results of previous writers such as Bartolomeo, et al, (2000), Faizah Mohd Khalid, Beverley Rae Lord and Keith Dixon (2012), experts also agreed that the concerns of related parties Customs is a driving force, a pressure or a compulsory for textile enterprises to implement the organization of environmental accounting. Concerns of stakeholders such as consumers (customers, distributors) who want to know whether products affect health or environmental pollution, investors want to know the information (money currency and non-monetary) on the environment in business reports, environmental reporting to agencies of the function or supervision of authorities, financial institutions consider the situation before loans, suppliers, ... According to experts, the observed variables are employees in the company do not have an impact on the organization of environmental accounting in textile enterprises.

Qualifications of employees: Employees in the enterprise are an important factor to conduct business activities. Experts believe that labor resources, skills, and qualifications of workers are an intangible asset of enterprises, which is one of the determinants of enterprise success, environmental accounting wants to be Applying to the enterprise requires the accounting team, relevant staff to have qualifications, knowledge, skills, sufficient knowledge of environmental accounting. This is similar to previous research results by Altohami Otman Alkisher (2013), Che Zuriana Muhammad Jamila, Rapiah Mohamedb, Faidzulaini Muhammadc, Amin Alid (2014). Experts also agreed that it would use university and collegelevel qualifications as a measure of employee qualification, while also examining specific accounting credentials. such as ACCA accounting, CPA, accounting practice certificate, accounting work experience, not using working skills observation variable and also re-agreeing the name of this factor is the qualifications of accountant.

Regulations: In the current context of Vietnam's socio-economic situation, letting businesses in general and textile enterprises in particular voluntarily carry out environmental protection activities, reduce environmental harm, providing environmental information (monetary and non-monetary information) is not feasible. Experts believe that only when there are regulations and pressures, will new businesses implement the implementation of environmental accounting. In other words, the implementation of environmental accounting in the textile business is to ensure compliance with Government regulations, to avoid penalties, fines, or withdraw business licenses. Therefore, experts agreed that regulations are factors that affect the organization of environmental accounting in textile enterprises in Vietnam. Under the pressure of coercion and government guidelines, the authorities will help make the environmental accounting organization in textile enterprises in Vietnam become more feasible. This idea is compatible with the results of Che Zuriana Muhammad Jamila, Rapiah Mohamedb, Faidzulaini Muhammadc, Amin Alid (2014), Chang (2007).

Perceptions of leaders on environment and environmental accounting: According to experts, the awareness of environmental leaders and environmental accountants will affect the organization of environmental accounting in textile enterprises in Ho Chi Minh City, experts explain that recognizing the benefits of environmental protection and environmental accounting will motivate business leaders to 
carry out environmental accounting in enterprises. In other words, when seeing the usefulness of environmental accounting, the leaders are ready to spend money and invest in implementing environmental accounting.

Based on previous studies in combination with qualitative research, the authors propose research hypotheses and models:

+ Hypothesis H1 - Related parties pay much attention to environmental issues of enterprises, the organization of environmental accounting will be more favorable.

+ Hypothesis H2 - The accounting staff in textile enterprises in Vietnam are trained and knowledgeable about environmental accounting, the organization of environmental accounting will be more favorable.

+ Hypothesis H3 - The organization of environmental accounting in textile enterprises in Vietnam will be more convenient when there are regulations of the competent authorities

+ Hypothesis H4 - The leaders of textile enterprises in Vietnam have environmental awareness and environmental accounting, the organization of environmental accounting for businesses will be more favorable.

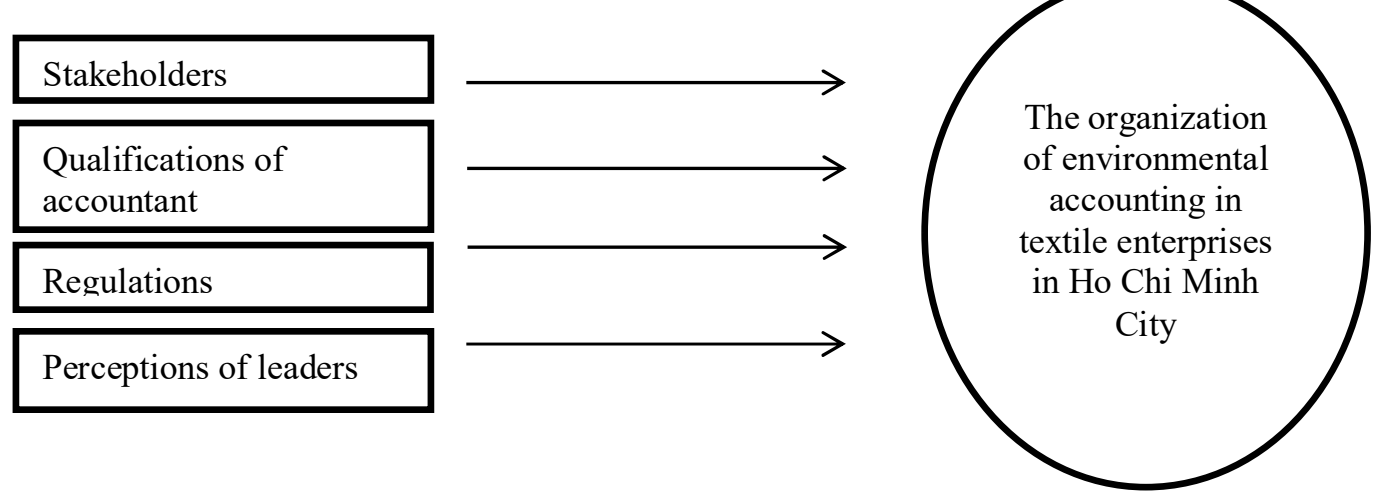

Source: synthetic author

Figure 1. Model of research on non-financial factors affecting the organization of environmental accounting in the textile industry in Ho Chi Minh City

\section{RESEARCH METHOD}

The research process comes from building a draft scale, followed by qualitative research, and finally quantitative research.

Building draft scale: Based on research theories combined with the reference of previous studies related to the organization of environmental accounting, the author has built a draft scale. The study of available relevant documents is an important issue in research, through the study of documents will help the author determine the research direction, propose research models and hypotheses as well like draft scale. Environmental accounting has been studied a lot in the world, but in Vietnam, the concept of environmental accounting is quite new, not much research on this issue especially the environmental accounting for the textile industry. Therefore, the research model, draft scales need to be adjusted and supplemented through discussion and expert opinions to ensure compliance with the characteristics of Vietnam. 
Qualitative research: After being proposed, the research model and draft scale will be discussed and consulted with experts. After discussing, consult the author experts to adjust and supplement for complete. The official scale will be used for quantitative research in the next section.

Table 1- Official scale for research

\begin{tabular}{|c|c|}
\hline $\begin{array}{c}\text { Variable } \\
\text { Code }\end{array}$ & Observation Variables \\
\hline STAK & Stakeholders \\
\hline STAK1 & $\begin{array}{l}\text { Customers have demand for environmental information related to products: } \\
\text { fabric, clothes of textile enterprises. }\end{array}$ \\
\hline STAK2 & $\begin{array}{l}\text { Investors require environmental information related to the production process } \\
\text { of textile, textile, dyeing, sewing, wash ... of textile enterprises to be } \\
\text { announced. }\end{array}$ \\
\hline STAK3 & $\begin{array}{l}\text { The Government closely monitors waste treatment related to weaving, dyeing, } \\
\text { wash processes, etc. textile enterprises }\end{array}$ \\
\hline STAK4 & $\begin{array}{l}\text { Other stakeholders (creditors, suppliers, ...) have demand for environmental } \\
\text { information related to products, textile enterprises }\end{array}$ \\
\hline QUAL & Qualifications of accountant \\
\hline QUAL1 & Accounting staff of textile and garment enterprises have a high degree \\
\hline QUAL2 & $\begin{array}{l}\text { Accountants of textile and garment companies have been granted domestic } \\
\text { certificates such as chief accountants, CFO, ... }\end{array}$ \\
\hline QUAL3 & $\begin{array}{l}\text { Accounting staff of textile and garment enterprises have been granted } \\
\text { international certificates on accounting and auditing such as ACCA, CPA, .. }\end{array}$ \\
\hline QUAL4 & $\begin{array}{l}\text { Accountants of textile and garment companies have many years of experience } \\
\text { in accounting, especially accounting of textile, dyeing and sewing products. }\end{array}$ \\
\hline REGU & Regulations \\
\hline REGU1 & $\begin{array}{l}\text { There are legal documents on the announcement or encouragement of textile } \\
\text { enterprises to publish a number of information related to environmental } \\
\text { accounting }\end{array}$ \\
\hline REGU2 & There are detailed instructions for implementing environmental accounting \\
\hline REGU3 & There are other regulations related to the environment (tax, statistics, ..) \\
\hline REGU4 & $\begin{array}{l}\text { There are penalties related to the treatment of wastewater and waste (starch, } \\
\text { dye, bleach) of textile enterprises }\end{array}$ \\
\hline PERC & Perceptions of leaders on environment and environmental accounting \\
\hline PERC1 & $\begin{array}{l}\text { Leaders of textile enterprises are aware of the usefulness, as well as difficulties } \\
\text { when organizing environmental accounting due to complicated production }\end{array}$ \\
\hline
\end{tabular}


THE IMPACT OF NON-FINANCIAL FACTORS ON THE ORGANIZATION OF ENVIRONMENTAL 35 ACCOUNTING IN TEXTILE ENTERPRISES IN HO CHI MINH CITY

\begin{tabular}{|c|l|}
\hline & processes (spinning, weaving, washing, dyeing, ...). \\
\hline PERC2 & Leaders of textile enterprises have knowledge about environmental accounting \\
\hline PERC3 & $\begin{array}{l}\text { Leaders of textile enterprises need to use information of environmental } \\
\text { accountants to make decisions }\end{array}$ \\
\hline PERC4 & $\begin{array}{l}\text { Leaders of textile enterprises have a clear sense of attitude and philosophy } \\
\text { about environmental protection and sustainable business. }\end{array}$ \\
\hline ORGA & The organization of environmental accounting in textile enterprises in Ho \\
\hline ORGA1 & Environmental accounting organization for environmental assets \\
\hline ORGA2 & Organizing environmental accounting for the part of the payable liabilities \\
\hline ORGA3 & Organization of environmental accounting for income, environmental benefits \\
\hline ORGA4 & Organization of environmental accounting for the part of environmental costs \\
\hline ORGA5 & $\begin{array}{l}\text { Organizing environmental accounting for the calculation of product prices for } \\
\text { textile enterprises }\end{array}$ \\
\hline ORGA6 & Organization of environmental accounting for the part of environmental budget \\
\hline ORGA7 & $\begin{array}{l}\text { Organization of environmental accounting for the announcement of } \\
\text { environmental accounting information for Textile enterprises }\end{array}$ \\
\hline
\end{tabular}

Quantitative research: After obtaining the official scale through qualitative research, the author will conduct a survey through survey forms. The number of survey samples was 310 votes, 303 votes were collected, 301 votes filled with enough information for data entry and analysis. The author will use SPSS software to test the scale, research model, research hypothesis through Cronbach Alpha methods, analysis of exploratory factors, then the author will test the level of correlation between independent variables and dependent variables by multivariate regression method.

\section{RESEARCH RESULTS AND DISCUSSION}

\subsection{Evaluate the reliability of the scale}

\section{Evaluate the scale through Cronbach's Alpha reliability coefficient}

This method allows analysts to remove unsuitable variables and limit processing of trash in the research model because otherwise we cannot know the exact variability as well as the error of the variables. Accordingly, only the variables with the correlation coefficient of total correlation (Corrected Item - Total Correlation) greater than 0.3 and Cronbach's Alpha coefficient of 0.6 or higher are considered acceptable and appropriate to be included in the next step. 
36 THE IMPACT OF NON-FINANCIAL FACTORS ON THE ORGANIZATION OF ENVIRONMENTAL ACCOUNTING IN TEXTILE ENTERPRISES IN HO CHI MINH CITY

Table 2. Scale test with Cronback Alpha reliability coefficient

\begin{tabular}{|c|c|c|c|c|}
\hline $\begin{array}{l}\text { Observation } \\
\text { Variables }\end{array}$ & $\begin{array}{l}\text { Scale Mean if } \\
\text { Item Deleted }\end{array}$ & $\begin{array}{l}\text { Scale Variance if } \\
\text { Item Deleted }\end{array}$ & $\begin{array}{l}\text { Corrected Item- } \\
\text { Total Correlation }\end{array}$ & $\begin{array}{l}\text { Cronbach's Alpha } \\
\text { if Item Deleted }\end{array}$ \\
\hline \multicolumn{5}{|c|}{ "STAK", Alpha= 0.910} \\
\hline STAK1 & 9.99 & 6.683 & .802 & .882 \\
\hline STAK2 & 9.93 & 6.982 & .786 & .887 \\
\hline STAK3 & 9.94 & 7.113 & .794 & .884 \\
\hline STAK4 & 9.84 & 7.463 & .812 & .880 \\
\hline \multicolumn{5}{|c|}{ "REGU", Alpha= .902 } \\
\hline REGU1 & 10.01 & 5.300 & .772 & .876 \\
\hline REGU2 & 9.90 & 5.157 & .817 & .859 \\
\hline REGU3 & 9.89 & 5.314 & .778 & .874 \\
\hline REGU4 & 9.88 & 5.643 & .755 & .882 \\
\hline \multicolumn{5}{|c|}{ "PERC", Alpha=.806 } \\
\hline PERC1 & 10.08 & 3.156 & .630 & .753 \\
\hline PERC2 & 10.10 & 3.158 & .674 & .730 \\
\hline PERC3 & 10.08 & 3.431 & .593 & .770 \\
\hline PERC4 & 10.05 & 3.464 & .589 & .771 \\
\hline \multicolumn{5}{|c|}{ "QUAL", Alpha=.893 } \\
\hline QUAL1 & 6.39 & 3.298 & .775 & .864 \\
\hline QUAL3 & 6.53 & 3.530 & .764 & .871 \\
\hline QUAL4 & 6.42 & 3.351 & .836 & .809 \\
\hline \multicolumn{5}{|c|}{ "ORGA", Alpha=.887 } \\
\hline ORGA1 & 20.1993 & 11.213 & .579 & .886 \\
\hline ORGA2 & 20.1728 & 11.083 & .739 & .863 \\
\hline ORGA3 & 20.2292 & 11.631 & .561 & .886 \\
\hline ORGA4 & 20.1761 & 11.286 & .749 & .863 \\
\hline
\end{tabular}


THE IMPACT OF NON-FINANCIAL FACTORS ON THE ORGANIZATION OF ENVIRONMENTAL 37 ACCOUNTING IN TEXTILE ENTERPRISES IN HO CHI MINH CITY

\begin{tabular}{ccccc}
\hline \hline ORGA5 & 20.1827 & 11.337 & .606 & .881 \\
\hline ORGA6 & 20.1728 & 11.117 & .792 & .858 \\
\hline ORGA7 & 20.1761 & 11.319 & .803 & .858 \\
\hline \hline
\end{tabular}

According to the data table, the indicators are shown as follows:

+ Cronback's Alpha coefficient of all scales is $>0.6$

+ Coefficients Correlated with the total variable of all factors in the scale are $>0.3$.

This proves that the scale used in the research model is appropriate and appropriate to analyze the next steps.

+ Particularly, the scale "Accountants have been granted domestic certificates as chief accountants, CFO" has Cronback's Alpha coefficients that transform components and coefficients correlated with unsatisfactory total variables so we exclude these scales .

Thus, after checking with the Cronback's Alpha coefficient, the appropriate observed variables will continue to EFA analysis to check the reliability (the excluded variable will not be included in the EFA) in the next step.

\section{Exploratory factors analysis - EFA}

KMO and Barlett's Test

When analyzing factors, the study put forward two hypotheses:

- Ho hypothesis: The variables in the overall are not correlated with each other.

- Hypothesis H1: The variables in the overall are correlated.

Table 3. KMO and Barlett inspection results

KMO and Bartlett's Test

\begin{tabular}{|l|l|r|}
\hline \multicolumn{2}{|l|}{$\begin{array}{l}\text { Kaiser-Meyer-Olkin Measure of Sampling } \\
\text { Adequacy. }\end{array}$} & .891 \\
\hline $\begin{array}{l}\text { Bartlett's Test of } \\
\text { Sphericity }\end{array}$ & Approx. Chi-Square & 2823.556 \\
\cline { 2 - 3 } & df & 105 \\
\cline { 2 - 3 } & Sig. & .000 \\
\hline
\end{tabular}

Source: data analysis

Barlett test results show that there are correlations between the variables in the overall $(\mathrm{sig}=0.000$ $<0.05$ rejecting $\mathrm{H} 0$, receiving $\mathrm{H} 1$ ). At the same time, coefficient $\mathrm{KMO}=.891>0.5$, proves that factor analysis to group variables together is appropriate and data is suitable for factor analysis. 
Table 4. Total Variance Explained

\begin{tabular}{|l|r|r|r|r|r|r|r|r|r|}
\hline \multirow{2}{*}{ Component } & \multicolumn{3}{|c|}{ Initial Eigenvalues } & \multicolumn{3}{c|}{ Extraction Sums of Squared Loadings } & \multicolumn{3}{c|}{ Loadings } \\
\cline { 2 - 12 } & Total & $\begin{array}{c}\text { \% of } \\
\text { Variance }\end{array}$ & $\begin{array}{c}\text { Cumulative } \\
\%\end{array}$ & Total & $\begin{array}{c}\text { \% of } \\
\text { Variance }\end{array}$ & $\begin{array}{c}\text { Cumulative } \\
\%\end{array}$ & Total & Variance & $\begin{array}{c}\text { Cumulative } \\
\%\end{array}$ \\
\hline 1 & 6.490 & 43.264 & 43.264 & 6.490 & 43.264 & 43.264 & 3.116 & 20.777 & 20.777 \\
\hline 3 & 1.940 & 12.933 & 56.197 & 1.940 & 12.933 & 56.197 & 3.110 & 20.735 & 41.512 \\
\hline 4 & 1.634 & 10.897 & 67.094 & 1.634 & 10.897 & 67.094 & 2.581 & 17.206 & 58.718 \\
\hline
\end{tabular}

The variance is $75,841 \%$ ( $>50 \%$ ), the factor loading factor of all variables is satisfactory $(>0.5)$. This is also the last factor analysis and these variables are taken into consideration for extracting factors in the next steps. The results of Table 5 show that according to Eigenvalue standard $>1,4$ factors are extracted and these 4 factors will explain $75.841 \%$ variation of data.

Table 5. Rotated Component Matrix ${ }^{\mathrm{a}}$

\begin{tabular}{|l|r|r|r|c|}
\hline & \multicolumn{5}{|c|}{ Component } \\
\cline { 2 - 5 } & 1 & 2 & \multicolumn{1}{c|}{3} & 4 \\
\hline REGU3 & .856 & & & \\
\hline REGU4 & .834 & & & \\
\hline REGU2 & .830 & & & \\
\hline REGU1 & .763 & .343 & & \\
\hline STAK4 & .257 & .852 & & \\
\hline STAK3 & & .847 & & \\
\hline STAK2 & & .785 & & \\
\hline STAK1 & .330 & .771 & & \\
\hline PERC2 & & & .816 & \\
\hline PERC4 & & & .801 & \\
\hline PERC3 & & & .736 & \\
\hline
\end{tabular}


THE IMPACT OF NON-FINANCIAL FACTORS ON THE ORGANIZATION OF ENVIRONMENTAL 39 ACCOUNTING IN TEXTILE ENTERPRISES IN HO CHI MINH CITY

\begin{tabular}{|l|l|l|r|r|}
\hline PERC1 & & & .728 & \\
\hline QUAL4 & & & & .888 \\
\hline QUAL3 & & & & .868 \\
\hline QUAL1 & & & & .844 \\
\hline
\end{tabular}

Source of data analysis

The variance is $75.841 \%$, and the factor loading of variables $(>0.5)$, so all variables are satisfactory. The method of extracting the main factor, varimax rotation to rotate the factor: turn the corner of the element to minimize the number of variables with a large coefficient at the same factor, thus enhancing the ability to explain the factor.

Table 6. Component Matrix ${ }^{\mathrm{a}}$

Component

1

\begin{tabular}{|l|r|}
\hline ORGA7 & .881 \\
\hline ORGA6 & .877 \\
\hline ORGA4 & .846 \\
\hline ORGA2 & .839 \\
\hline ORGA5 & .693 \\
\hline ORGA1 & .672 \\
\hline ORGA3 & .653 \\
\hline
\end{tabular}

Extraction Method:

Principal Component

Analysis.

a. 1 components

extracted.

Source of data analysis

According to the data of Table 6, the value of $\mathrm{Y}$ variable is quite large $(>50 \%)$, so the collected data is suitable for extracting the factors and can be used for subsequent regression analysis.

\subsection{Multivariate regression analysis}

\section{Testing the suitability of the model}

Method of significance test (ANOVA analysis) is a hypothesis test of the relevance of the overall linear regression model. The idea of this test is about the linear relationship between the dependent variable $\mathrm{Y}$ that relates the entire set to the independent variables. 
Table 7. ANOVA

\begin{tabular}{|c|c|c|c|c|c|c|}
\hline \multicolumn{7}{|c|}{ ANOVA $^{a}$} \\
\hline \multicolumn{2}{|c|}{ Model } & $\begin{array}{l}\text { Sum of } \\
\text { Squares }\end{array}$ & $\mathrm{df}$ & Mean Square & $\mathrm{F}$ & Sig. \\
\hline \multirow[t]{3}{*}{1} & Regression & 68.320 & 4 & 17.080 & 210.873 & $.000^{\mathrm{b}}$ \\
\hline & Residual & 23.975 & 296 & .081 & & \\
\hline & Total & 92.295 & 300 & & & \\
\hline
\end{tabular}

Source of data analysis

According to the data in Table 7, the ANOVA test results with significant significance of sig $=0,000$ showed that the linear regression model was built in accordance with the collected data.

\section{Results of multivariate linear regression analysis}

The regression coefficients of each independent variable in the multiple linear regression model are called partial regression coefficients. The meaning of this coefficient is to measure the change in the mean $\mathrm{Y}$ when $\mathrm{X}_{\mathrm{k}}$ changes a unit, keeping the remaining independent variables unchanged.

Table 8: Statistical parameters in regression model.

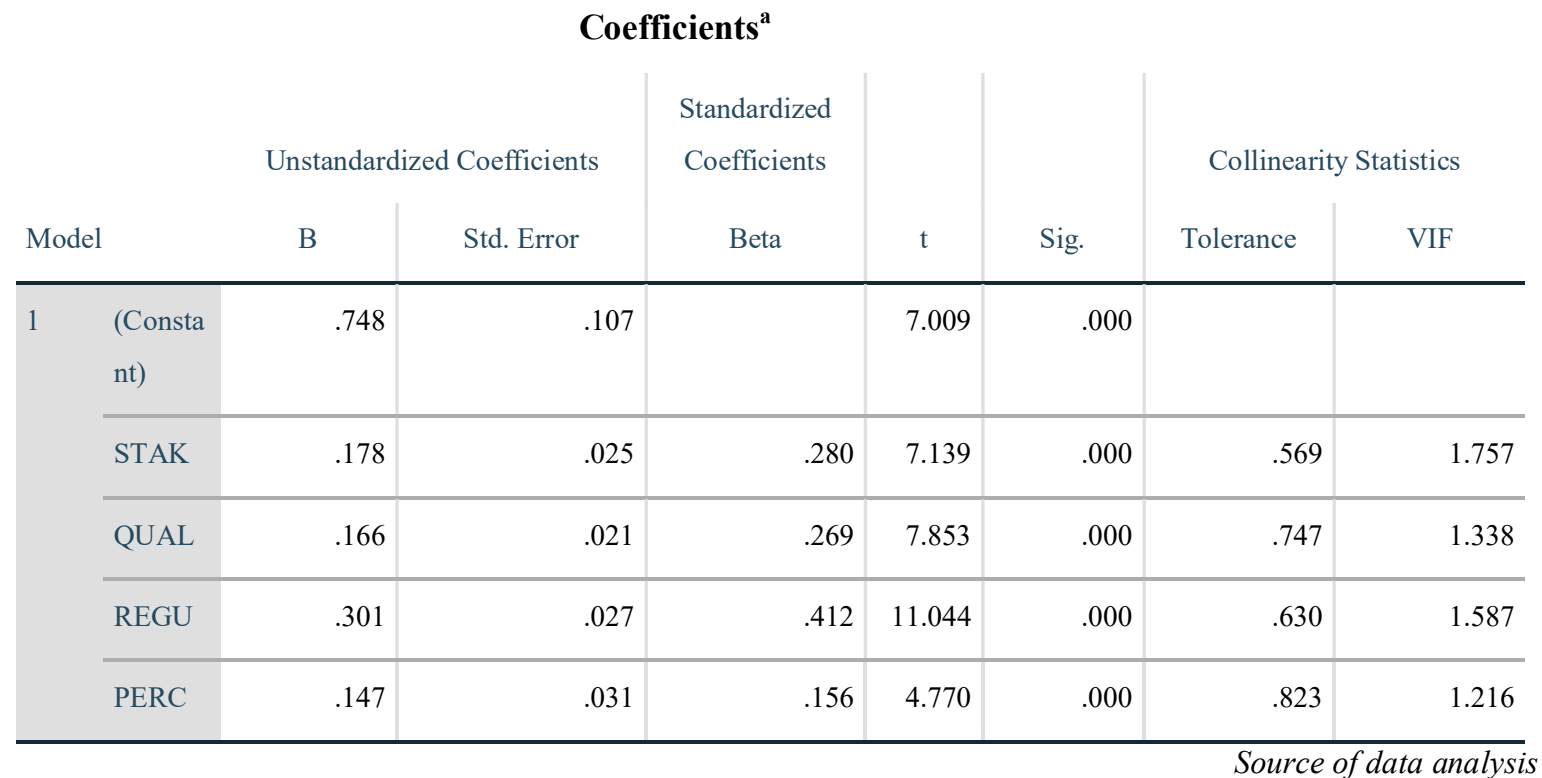

In table 8 , the coefficient VIF of the Beta coefficients is less than 10 and the Tolerance coefficient is equal to $>0.5$, indicating that no multicollinearity phenomenon occurs. On the other hand, the significance of the two-way verification between the independent variables and the dependent variables is satisfied (Sig. 2 -tailed $=0,000<0.05$ ).

The multiple regression equation is expressed in the following form:

$$
O R G A=0.280 S T A K+0.269 Q U A L+0.412 R E G U+0.156 P E R C
$$




\section{Level of explanation of the model}

Table 9: Assessing the suitability of the multivariate linear regression model

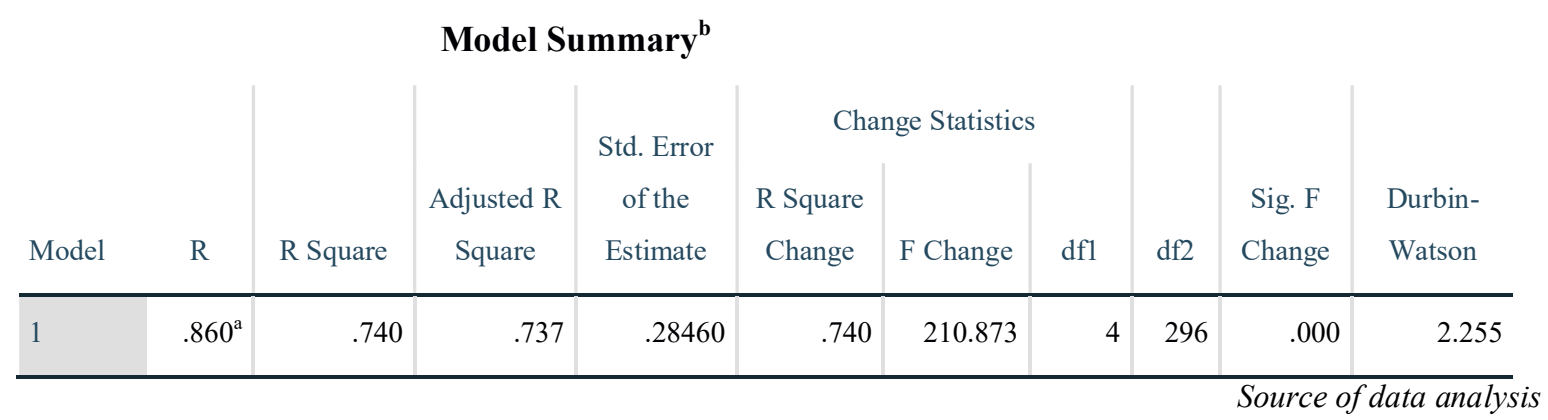

Table 9 shows that the correlation coefficient value is $0.860>0.5$. Therefore, this is an appropriate model to use to evaluate the relationship between dependent variables and independent variables. The determination coefficient of the adjusted R2 regression model is 0.737 . This indicates about $73.7 \%$ of variation in non-financial factors affecting the organization of environmental accounting in textile enterprises in Ho Chi Minh City, can be explained from the linear relationship between variable $\mathrm{Y}$ and independent variables.

+ Check for variance change: The standardized residual graph randomly disperses around axis 0 , so we can conclude that there are no signs of variance change.

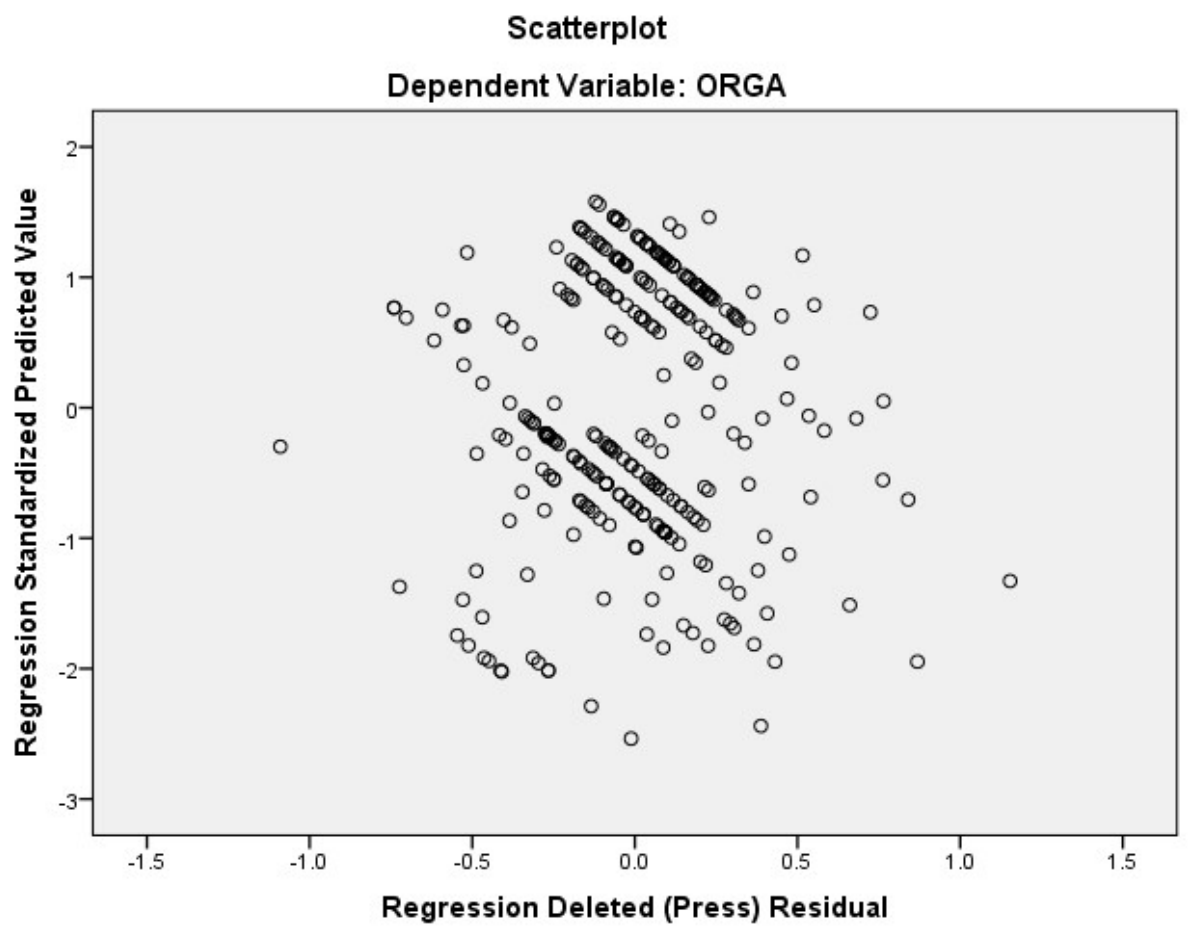

+ Checking the autocorrelation phenomenon: The above analysis results (Table 9) show that DurbinWatson coefficient $\mathrm{d}=2.255(1<\mathrm{d}<3)$, so the model does not have the correlation phenomenon. 


\section{Assessing the importance of non-financial factors affecting the organization of environmental accounting in textile enterprises in Ho Chi Minh City.}

The multiple regression equation is expressed in the following form:

$$
O R G A=0.280 S T A K+0.269 Q U A L+0.412 R E G U+0.156 P E R C
$$

Thus, four factors include: Stakeholders (STAK), Qualifications of accountants in enterprises (QUAL), Regulations (REGU), Perceptions of leaders on environment and environmental accounting (PERC) are available positively affects the organization of environmental accounting in textile enterprises in Ho Chi Minh City. In these 4 factors, the factors of regulations that have a significant influence on the environmental accounting organization are coefficient $\beta=0.412$, the next order includes stakeholders $(\beta=$ $0.28)$, qualification accountant $(\beta=0.269)$, leadership's perception of environmental accounting $(\beta=$ 0.156). Thus, hypotheses $\mathrm{H} 1, \mathrm{H} 2, \mathrm{H} 3, \mathrm{H} 4$ for formal theoretical research models are accepted.

Table 10. The level of contribution of non-financial factors to the organization of environmental accounting in the textile industry in Ho Chi Minh City

\begin{tabular}{|l|c|r|}
\hline Factor & $\begin{array}{c}\text { Regression } \\
\text { coefficient }\end{array}$ & Contribution level \\
\hline Regulations & 0.412 & $36.9 \%$ \\
\hline Related parties & 0.280 & $25.1 \%$ \\
\hline Accounting staff qualifications & 0.269 & $24.1 \%$ \\
\hline Perceptions of Leaders & 0.156 & $14.0 \%$ \\
\hline
\end{tabular}

\subsection{Discussion}

After analyzing the data and presenting the research results on the influence of the factors of "Regulations", "Stakeholders", "Qualifications of accountants", "Perceptions of leaders on environment and environmental accounting" to the organization of environmental accounting in the textile and garment industry in Ho Chi Minh City.

It can be seen that if you want to organize an effective environmental accounting work without interruption, the most important thing is the "Regulations", only when there are regulations of pressures will the new businesses implement . In other words, the implementation of environmental accounting in the textile business is to ensure compliance with Government regulations, to avoid penalties, fines, or withdraw business licenses. In recent years, Vietnam in general and Ho Chi Minh City in particular have constantly changed, reforming administrative procedures, policies, infrastructure ... to create a favorable and favorable environment for Domestic and foreign investors conduct investment and production activities in general and textile and garment industry in particular. Many policies are in place, including changes from accounting laws, standards and regimes, but there are still no guidelines on environmental accounting. Therefore, the organization of field accountants is more or less affected.

"Stakeholders" - the concern of the parties involved in the business is a driving force, a pressure or a mandatory for the textile business to implement the organization of environmental accounting. The textile and garment industry's products are more and more diversified and diversified from low to high quality, contributing to meeting the increasing and diversified demands of consumers. According to Ho Chi Minh City Department of Industry and Trade, the main export market of Ho Chi Minh City's textiles is the US, UK, Japan, Canada and South Korea (Saigon Giai Phong Newspaper online). Large markets, especially developed countries, often have strict requirements for quality, safety, hygiene, and environment. Increasing difficulties in the production process as well as increasing costs for businesses. Therefore, the role of the authorities is very large, need to closely monitor the production process to ensure the 
production does not cause harm, environmental pollution, parameters related to the environment. products must be transparent and at the same time not for some businesses for their own interests, which affect the whole textile industry, not only losing customers but also affecting the decision-making of investors. The authorities, customers, investors, ... create a significant pressure on the organization of environmental accounting in textile enterprises.

The factor "Qualifications of accountants", according to Ho Chi Minh City Department of Industry and Trade, until the end of 2018 Ho Chi Minh City had 4,141 textile enterprises. In addition to a small number of workers who have been trained through a formal school, most of the education level of workers in the textile industry only stops at high school graduation, not yet training in industry, when working, most workers must work while learning, over time, the employees have gradually matured, progressed, matured at work. By creating conditions for both working and studying, the DMVN industry has gradually created higher quality human resources than the original. As for the qualifications of accountants, even though most accountants have a training course on accounting, there is no place for training in environmental accounting, so the organization of environmental accounting will face certain difficulties.

"Perceptions of leaders on environment and environmental accounting" also has a relatively high impact on the organization of environmental accounting work in the textile industry in Ho Chi Minh City. The textile and garment industry has brought a lot of benefits from creating jobs for workers, increasing income, creating products to serve the needs of the people, helping the economy of Ho Chi Minh City develop, ... .. We cannot deny the great benefits from the textile and apparel industry, however, besides the benefits, the development of the textile and garment industry also has significant impacts on the living environment and the natural environment. around. A lot of emissions, sewage, and waste generated from the textile and garment production and business impact the surrounding air, water and soil environment. In addition, although regional and international integration is an opportunity for Vietnam's textile and apparel industry, it is also accompanied by many challenges due to the inherent limitations of Vietnam's textile industry in general and Ho Chi Minh City. In particular, raw materials depend heavily on foreign countries, experience, weak management skills, small capital, etc. The elimination of quotas when participating in WTO by members also makes Vietnam textile and garment industry must compete more with international competitors. In addition to strong competitors from China, India and Bangladesh, new rivals from countries such as Myanmar, Cambodia, etc. due to insurance, tax, ... costs of these countries are lower than with Vietnam. Meanwhile, inputs such as materials, labor costs, social insurance, related services, etc. tend to increase rapidly. Therefore, if the leaders of textile enterprises do not have a philosophy, awareness of sustainable business, environmental protection, the production of environmental pollution is inevitable, and the organization of environmental accounting is close to as impossible, because business leaders do not realize the benefits of organizing environmental accounting and reducing costs to achieve economic benefits.

\section{CONCLUSIONS AND RECOMMENDATIONS}

According to Ho Chi Minh City Department of Industry and Trade, in 2017, the textile and garment industry accounted for $13.34 \%$ of the industry's total production value, export turnover reached US \$ 5.3 billion. In the first 6 months of 2018, the city's textile export turnover reached nearly 2.6 billion USD, accounting for $17.2 \%$ of the city's total export turnover, up $2.8 \%$ compared to 2017 . (Saigon Giai Phong Newspaper online). This shows that the textile and garment industry is one of the important sectors and contributes greatly to the development of Ho Chi Minh City. Environmental accounting in textile enterprises must also be concerned, because this is the information center of enterprises, honest and transparent accounting information will also contribute to the development of the textile industry. According to the results of the regression model, the study found a positive and statistically significant impact including 4 factors "Regulations", "Stakeholders", and "Qualifications of accountants", "Perceptions of leaders on environment and environmental accounting" to the organization of environmental accounting in textile enterprises in Ho Chi Minh City. Therefore, the author proposes some recommendations as follows: 


\section{THE IMPACT OF NON-FINANCIAL FACTORS ON THE ORGANIZATION OF ENVIRONMENTAL ACCOUNTING IN TEXTILE ENTERPRISES IN HO CHI MINH CITY}

Firstly, the functional officials and professional organizations need guidelines and regulations to make the implementation of environmental accounting more convenient and more consistent make the information more published, more honest.

Second, the role of stakeholders is huge. Stakeholders need more attention, more demand for environmental information, as well as information on environmental accounting that will help with the implementation and disclosure of environmental-related information of businesses more and more.

Third, improving qualifications for accountants. There should be courses and workshops to help accountants gain more knowledge about accounting in general and environmental accounting in particular. Higher education colleges that teach accounting need to include more knowledge about environmental accounting into the curriculum for students.

Fourth, from the perspective of business leaders, owners, business leaders need to change their views on the environment and the role of environmental accounting information to influence the implementation of accounting. more environment. Business leaders need to realize the financial benefits to non-financial environmental accountants bring. Enterprises need to actively protect the environment and participate in environmental protection and sustainable business activities.

\section{REFERENCES}

[1] Bui Thi Thu Thuy, 2010. Research on management and accounting of environmental costs in Vietnamese coal mining enterprises. Economic PhD thesis, University of Mining - Geology

[2] Ha Xuan Thach, 2014. Orientation for developing environmental management accounting in Vietnamese accounting system. Proceedings of Workshop "Accounting and Auditing in the process of reform and integration" (September 8, 2014) - Danang University

[3] Hoang Thi Dieu Linh, 2013. Environmental financial accounting and application orientation in Vietnam. Master thesis of University of Economics Ho Chi Minh City.

[4] Hoang Thi Bich Ngoc, 2017. Management of environmental cost management

[5] in oil and gas processing enterprises of Vietnam National Oil and Gas Group. Doctoral thesis in Economics of Commercial University.

[6] Huynh Duc Long, 2016. Environmental accounting of countries in the world and lessons learned for Vietnam. Website of Vietnam Association of Accountants and Auditors [online] Available at: $<$ http://vaa.net.vn/Tin-tuc/Tin-chi-tiet/newsid/3852/Ke-toan-moi- school-school-student-school-student-inthe-world-school-education-for-Vietnam-Vietnam>. [Accessed 10 May 2017]

[7] Nguyen Dinh Tho, 2013. Methods of scientific research in business. Ho Chi Minh City: Finance Publisher.

[8] Nguyen Thanh Tai, 2012. Organization of environmental cost accounting for alcoholic beverage enterprises in the southern key economic region. Master thesis. Ho Chi Minh City University of Economics.

[9] Pham Duc Hieu, 2010. Accounting of environmental costs in enterprises and the irrationalities of traditional cost accounting. Journal of Economic Development, Số 241/2010, pages 34-38.

[10] Pham Duc Hieu, Tran Thi Hong Mai, 2012. Environmental accounting in enterprises. Vietnam Education Publishing House.

[11] Pham Hoai Nam, 2016. Completing the organization of environmental accounting work in manufacturing enterprises in Quang Ngai province. Economic doctoral thesis of Institute of Finance. 
THE IMPACT OF NON-FINANCIAL FACTORS ON THE ORGANIZATION OF ENVIRONMENTAL 45 ACCOUNTING IN TEXTILE ENTERPRISES IN HO CHI MINH CITY

[12] Trinh Hiep Thien, 2010. Applying environmental management accounting to Vietnamese manufacturing enterprises. Master thesis - University of Economics Ho Chi Minh City

[13] Altohami Otman Alkisher, 2013. Factors influencing environmental management accounting adoption in oil and manufacturing firms in Libya. A thesis for the degree of Doctor of Philosophy, Universiti Utara Malaysia, December 2013.

[14] Bartolomeo, M.; Bennett, M.; Bouma, J.J.;Heydkamp, P.; James, P.\& Wolters, T. (2000). Environmental management accounting in Europe: current practice and future potential. The European Accounting Review, 9, 1:31-52.

[15] Che Zuriana Muhammad Jamila, Rapiah Mohamedb , Faidzulaini Muhammadc, Amin Alid, 2014. Environmental management accounting practices in small medium manufacturing firms. Procedia - Social and Behavioral Sciences 172 ( 2015 ) $619-626$.

[16]Faizah Mohd Khalid, Keith Dixon, 2012. Environmental management accounting implementation in Environmentally sensitive industries in Malaysia. 6th NZ Management Accounting Conference. Massey University, Palmerston North, 22-23 Nov 2012.

[17] Huei-Chun Chang, 2007. Environmental management accounting within universities: current state and future potential. A thesis for the degree of Doctor of Philosophy, RMIT University, November 2007

[18]IFAC, 2005. International Guidance Document Environmental Management Accounting. [online] Available $\quad$ at: $\quad<$ https://www.ifac.org/publications-resources/international-guidance-documentenvironmental-management-accounting $>$. [Accessed 10 May 2015].

Received on February 1st, 2019

Accepted on March 25th, 2019 